\title{
Cytology of islet tumours and hyperplasias associated with the Zollinger-Ellison syndrome
}

\author{
C. CAVAllero, E. SOLCiA, AND R. SAMPIETRO \\ From the Institute of Pathological Anatomy, the University of Pavia, Italy
}

EDITORIAL COMMENT These studies suggest that the tumours and the hyperplastic growths are not related to insulin-producing $\beta$ cells or to glucagon-producing $\alpha$ cells but may originate from argyrophilmetachromatic or $\delta$ cells which may secrete gastrin.

Since Zollinger and Ellison described in 1955 a pathological entity consisting of multiple recurrent peptic ulcerations, gastric hypersecretion, and islet cell tumours of the pancreas, several reports have been published dealing with the clinical and biological aspects of this new syndrome (Priest and Alexander, 1957;Summerskill, 1959; Gregory, Tracy, French, and Sircus, 1960; Grossman, Tracy, and Gregory, 1961; Hallenbeck, Code, and Kennedy, 1961 ; Zollinger, Elliott, Endahl, Grant, Goswitz, and Taft, 1962; Selli, Baglioni, and Castrini, 1963; Sircus, 1964). Neoplastic or hyperplastic growths of the pancreatic islets have been considered to play an important pathogenetic role by secreting an 'ulcerogenic' factor very similar or, perhaps, identical with, the antral hormone gastrin (Gregory et al., 1960; Gregory and Tracy, 1964).

Recent morphological studies have shown that in pancreatic islets of man and several vertebrate species, in addition to the $\alpha$ and $\beta$ cells, there exists a third cell type with cytological and cytochemical characters which are quite different from those of other cell types. This cell has been labelled the $\alpha_{1}$ cell (Hellman, Rothman, and Hellerström, 1962; Petersson, Hellerström, and Hellman, 1962) or, on the basis of its staining properties, the argyrophilmetachromatic cell (Cavallero and Solcia, 1963, $1964 a, b)$. Previous researches from this laboratory suggest that $\delta$ cell, as described by Bloom (1931) and Thomas (1937) in pancreatic islets of man and vertebrates, is likely to be identical with our argyrophil-metachromatic cell (Solcia and Sampietro, 1965a).

On the basis of these data, it has seemed interesting to study pancreatic tumours and hyperplasias associated with the Zollinger-Ellison syndrome by applying the most reliable methods for islet cytology. The main purpose of this investigation has been to ascertain a possible role for the argyrophil-metachromatic cell in the histogenesis of such neoplastic growths.

\section{MATERIAL AND METHODS}

Three islet carcinomas (cases 1, 2, 3), one multiple adenomatosis (case 4), and two islet hyperplasias (cases $5,6)$ from patients with the Zollinger-Ellison syndrome were examined. Apart from case 3, being found at necropsy, the tissue samples were obtained from surgical specimens. The material was partly fixed in Bouin's fluid for 24 hours (cases 1, 4, 6), partly in formol for different times ranging from 24 hours to one year (cases 2, 3, 4, 6), partly in Bouin and subsequently stored in formol for several months (case 5); a formol-fixed specimen was refixed in Bouin before embedding (case 2). For comparison, surgical and necropsy material from unaltered human pancreases fixed in $10 \%$ formol, Bouin, $6 \%$ glutaraldehyde or in a glutaraldehyde-picric acid-sodium-acetate mixture, was also examined. Furthermore, Bouin-fixed samples of two islet $\beta$ cell adenomas and two formol-fixed intestinal carcinoids were studied.

Paraffin sections of all tissues were stained with the aldehyde-fuchsin (Scott, 1952) and the pseudo-isocyanin (Schiebler and Schiessler, 1959) methods for islet $\beta$ cells. Other sections were treated with Bodian's silver impregnation (McManus and Mowry, 1960) and dimethylaminobenzaldehyde (D.M.A.B.)-nitrite reaction for proteinbound tryptophan (Lison, 1960) on the grounds of the alleged specificity of these methods for $\alpha$ cells. For $\delta$ cells toluidine-blue metachromatic stain (Manocchio, 1960) and Davenport's silver impregnation (Hellerström and Hellman, 1960) were employed; sometimes methylation (Fisher and Lillie, 1954) or methylation followed by demethylation (Lillie, 1958) were performed before staining with toluidine blue. Phosphotungstic acidhaematoxylin (P.T.A.H.) stain (McManus and Mowry, 1960), Barrnett and Seligman's (1958) method for protein carboxyl groups with or without the $\mathrm{NaOH}$ test according to Karnovsky and Fasman (1960) for distinguishing between side-chain and terminal carboxyl groups, and 
TABLE I

TUMOUR OR HYPERPLASTIC ISLET CELLS IN THE ZOLLINGER-ELLISON SYNDROME COMPARED WITH NORMAL ISLET CELLS

\begin{tabular}{|c|c|c|c|c|c|c|}
\hline Material & $\begin{array}{l}\text { Toluidine } \\
\text { Blue ( } \mathrm{pH} \text { 5) }\end{array}$ & Davenport & Bodian & $\begin{array}{l}\text { D.M.A.B.- } \\
\text { nitrite }\end{array}$ & $\begin{array}{l}\text { Aldehyde- } \\
\text { fuchsin }\end{array}$ & $\begin{array}{l}\text { Pseudo- } \\
\text { isocyanin }\end{array}$ \\
\hline \multicolumn{7}{|l|}{ Normal pancreatic islets } \\
\hline$a$ cells & - & - & $++t$ & ++ & - & - \\
\hline$\beta$ cells & - & - & - & - & +++ & ++- \\
\hline$\delta$ (argyrophil-metachromatic) cells & ++ & +++ & +++ & + & - & - \\
\hline \multicolumn{7}{|l|}{ Zollinger-Ellison tumours and hyperplasias } \\
\hline Case 1 (carcinoma) & ++ & $+t$ & $t+$ & - & - & - \\
\hline Case 2 (carcinoma) & + & + & + & + & \pm & - \\
\hline Case 3 (carcinoma) & + & + & + & \pm & 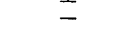 & - \\
\hline Case 4 (adenomatosis) & + & ++ & + & + & - & - \\
\hline Case 5 (hyperplastic cells) & + & ++ & ++ & - & - & - \\
\hline Case 6 (hyperplastic cells) & ++ & ++ & +++ & + & - & - \\
\hline
\end{tabular}

toluidine-blue stain at $p \mathrm{H} 5$ after $\mathrm{HCl}$ and $\mathrm{KOH}$ treatment for 'masked' basophilia (Solcia and Sampietro, 1965c) were also employed. Finally, diazonium, MassonHamperl and Schmorl reactions (Pearse, 1960) were used as histochemical tests for argentaffin cells.

\section{RESULTS}

NORMAL PANCREATIC ISLETS As shown by Table I (upper part), non-neoplastic human islets appeared to be composed of three cell types with a different histological and histochemical reactivity. $\beta$ cells were easily distinguished by their reactivity to the pseudo-isocyanin and aldehyde-fuchsin methods. The positivity to the Bodian and to the D.M.A.B.nitrite methods was common for both $\alpha$ and $\delta$ cells, although the reactivity of $\delta$ cells for D.M.A.B.nitrite was very weak. The morphological differentiation between these two cell types was achieved only on the basis of the selective positivity of $\delta$ cells for Davenport's silver impregnation and toluidine blue

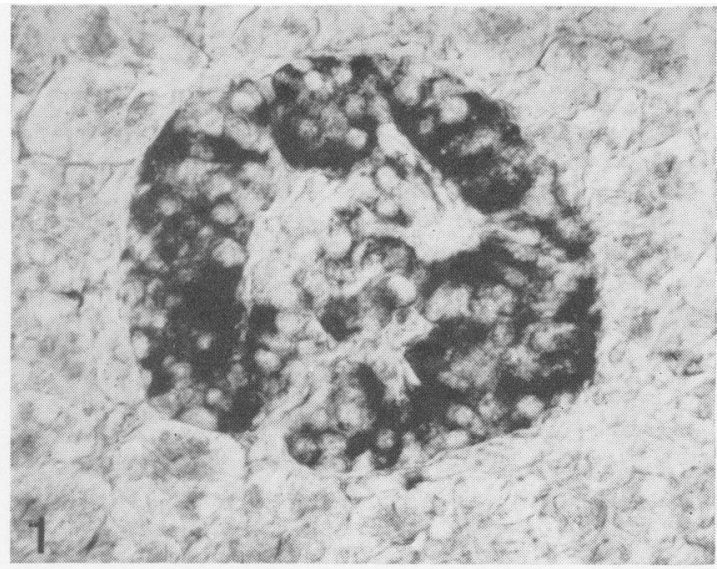

FIG. 1.

FIGS. 1 and 2. Normal islet showing high numbers of closely packed $\beta$ cells (1) compared with a hyperplastic islet from a Zollinger-Ellison case showing scarce and irregularly scattered $\beta$ cells (2).

Aldehyde-fuchsin stain $\times 450$ and $\times 120$. red metachromasia at $p \mathrm{H} 5 . \delta$ cells were not stained by toluidine blue at $p \mathrm{H} 4$ or after methylation of tissue sections; when alkali demethylation followed methylation the metachromatic stain at $p \mathrm{H} 5$ was restored.

As regards the other methods employed, both $\alpha$ and argyrophil-metachromatic cells, differing from $\beta$ cells, reacted positively to Barrnett and Seligman's reaction, which was completely prevented by $\mathrm{NaOH}$ treatment according to Karnovsky and Fasman (1960), as well as to the method for 'masked' basophilia; $\alpha$ cells reacted more strongly than $\delta$ cells to the P.T.A.H. stain. Histochemical tests for argentaffin cells gave constantly negative results.

TUMOUR AND HYPERPLASTIC ISLETS As reported in Table I (lower part), tumour and hyperplastic cells from Zollinger-Ellison cases showed no cytological relationships to the islet $\beta$ cells; in fact, they never reacted to the aldehyde-fuchsin stains (Figs. 1 and 2)

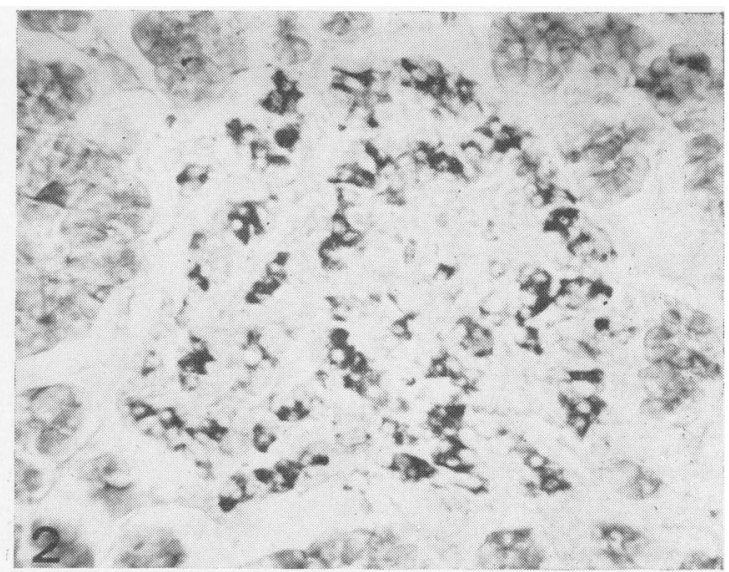

FIG. 2. 
and to the more reliable pseudo-isocyanin method. A very weak staining of these cells by aldehyde-fuchsin in case 2 was of non-granular nature and in no way resembled that of specific beta-granules stored in the cytoplasm of $\beta$ cells. Two insulinomas studied comparatively appeared to be composed partly of cells displaying aldehyde-fuchsin- and pseudo-isocyaninpositive granules, partly of agranular cells.

Tumour and hyperplastic islet cells reacted to the Bodian silver impregnation (Figs. 3 and 4) and the D.M.A.B.-nitrite test which have been considered as specific stains for $\alpha$ cells; however, as noted before, these methods stain normal $\delta$ cells too. In our cases, the reactivity of tumour cells for D.M.A.B.-nitrite was more comparable to the weak reactivity of $\delta$ cells, than to the moderate positivity of $\alpha$ cells. As shown in Table I, both tumour and hyperplastic cells in Zollinger-Ellison cases were metachromatically stained by toluidine blue (Figs. 5 and 6 ) and silver impregnated by Davenport's method (Figs. 7 and 8), although marked differences were observed in the degree of stain from one case to another and, in the same case, from one cell to another. Different fixation of various samples might account in part for these differences; Bouin-fixed tissues reacted far better than formol-fixed ones. On the other hand, a different degree of anaplasia might explain the variable reactivity of the cells observed in the same tissue section. Some sections previously stained with toluidine blue were drawn or photographed and subsequently silver impregnated; thus, it was ascertained that cytoplasmic granules showing metachromasia are also argyrophil and that there is a good correspondence between the amount of metachromatic material and the degree of silver impregnation.

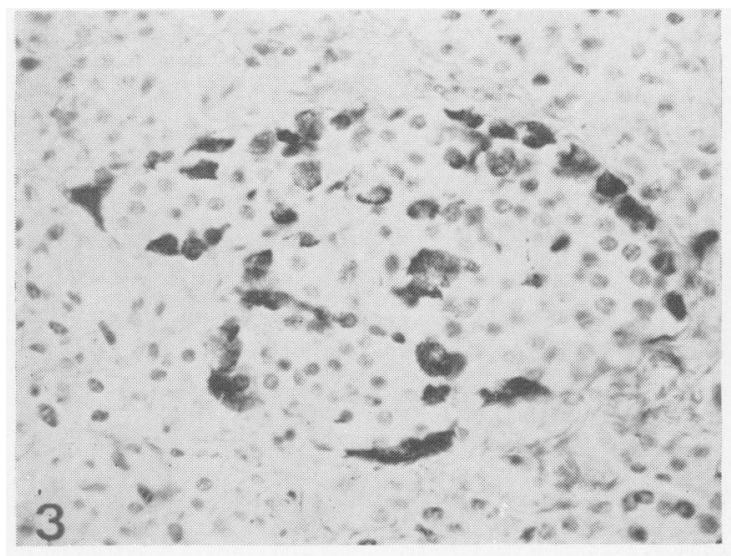

FIG. 3 .
It should be noted that tumour and hyperplastic cells in Zollinger-Ellison cases, like normal $\delta$ cells, stained metachromatically with toluidine blue at $p \mathrm{H}$ 5 both directly or after $\mathrm{HCl}$ and $\mathrm{KOH}$ 'unmasking' treatments; further, no staining was observed with toluidine blue at $p \mathrm{H} 4$ or after methylation, although alkali demethylation restored their stainability. These histochemical data indicate that carboxyl groupings are involved in the metachromatic reaction. A positive reaction for the Barrnett and Seligman method, which was completely prevented by the $\mathrm{NaOH}$ treatment, confirms this hypothesis and suggests that we are dealing with side-chain carboxyl groups of proteins. Some weak positivity was observed for the P.T.A.H. method. By using the histochemical methods for argentaffin cells, highly positive reactions were found in carcinoid tumours, whereas Zollinger-Ellison tumours and hyperplasias gave constantly negative results.

\section{DISCUSSION}

In islet-cell pathology, the existence of insulinproducing $\beta$ cell tumours or insulinomas is fully accepted, while only few glucagon-producing $\alpha$ cell tumours have been reported and their endocrine activity is widely questioned. Till now, there is no agreement as regards the histogenesis of the ZollingerEllison tumours. A possible origin from glucagonproducing $\alpha$ cells was originally suggested (Zollinger and Ellison, 1955; Greider and Elliott, 1964), but several findings do not support such a hypothesis, (Zollinger and Craig, 1960; Rawson, England, Gillam, French and Stammers, 1960; Marks, Selzer, Louw, and Bank, 1961; Martin and Potet, 1962; Brown and Crile, 1964). It is now generally believed

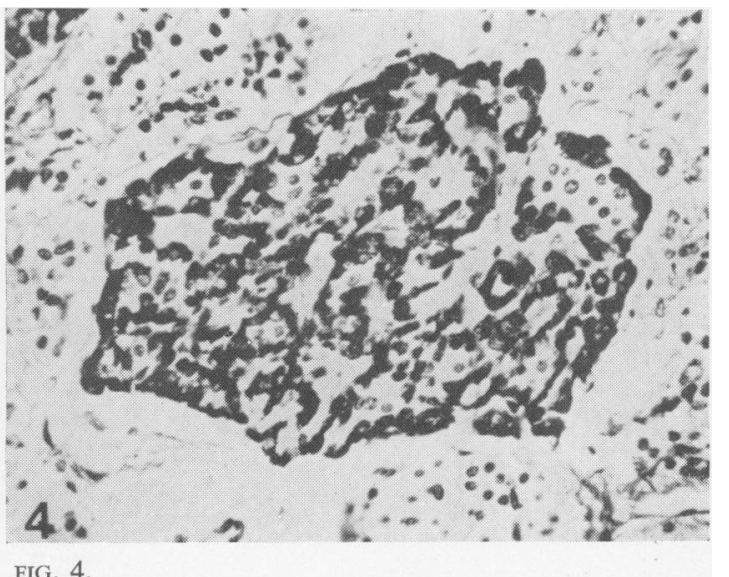

FIG. 4. 


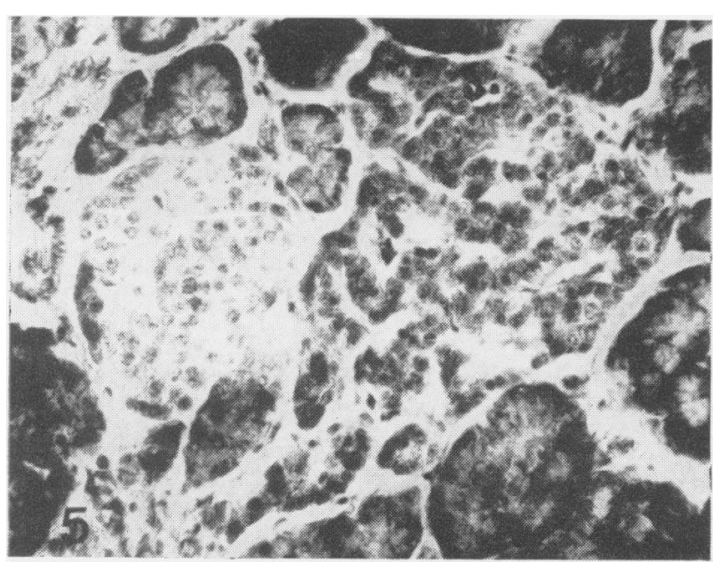

FIG. 5.

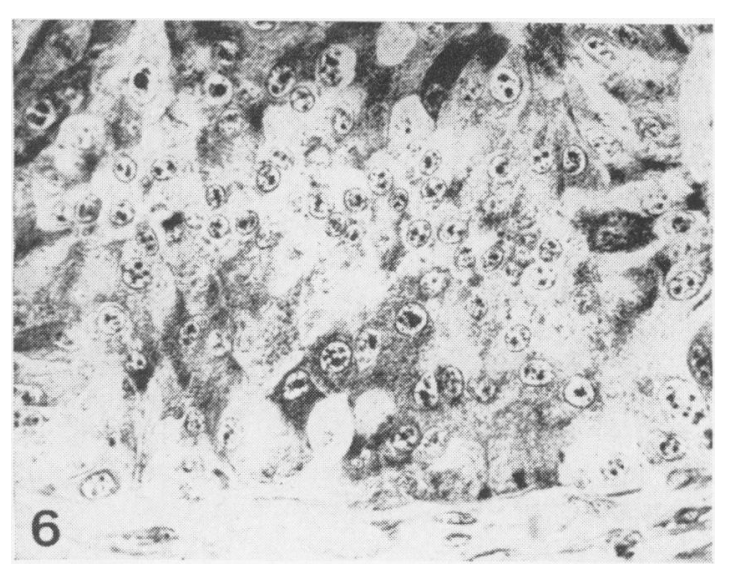

FIG. 6.

FIG. 5. Islet hyperplasia. Cords of hyperplastic metachromatic cells adjacent to a residual non-hyperplastic islet. Toluidine blue stain at $\mathrm{pH} 5 . \times 250$.

FIG. 6. Islet carcinoma showing various amounts of metachromatic granules in the cytoplasm of tumour cells. Toluidine blue stain at $\mathrm{pH} 5 . \times 600$.

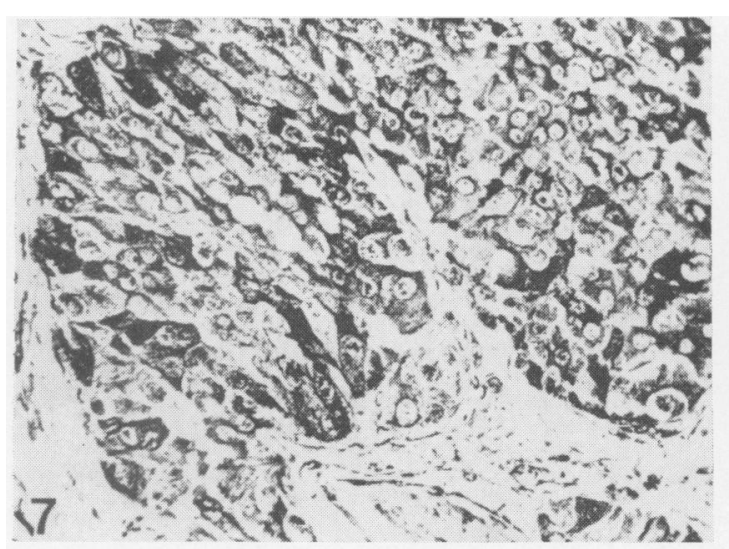

FIG. 7.

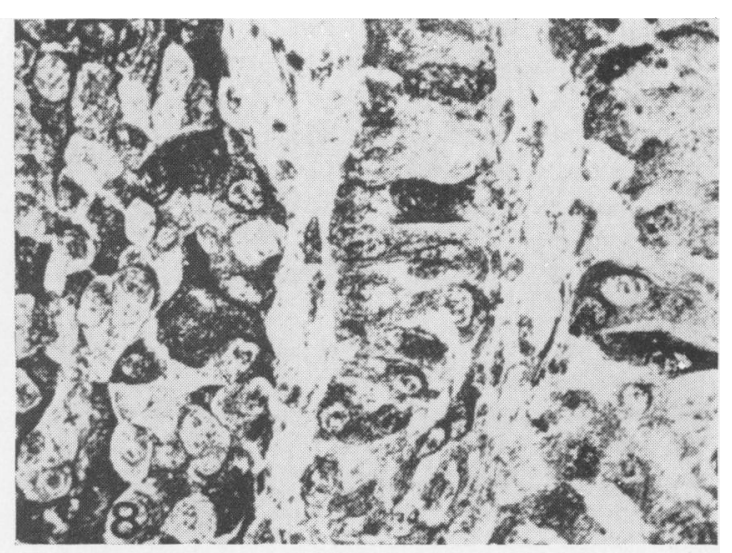

FIG. 8.

FIGS. 7 and 8. Silver-impregnated tumour cells in islet carcinomas. Davenport silver impregnation. $\times 250$ and 700 .

that no relationships exist between the ZollingerEllison tumour and islet $\beta$ cells.

Bloom (1931) and Thomas (1937) have reported that a third granular cell type, named $\delta$ cell, takes part in the composition of islet tissue both in man and several vertebrate species. Recent morphological investigations using more reliable methods, such as Davenport's silver impregnation (Hellman et al., 1962; Cavallero and Solcia, 1964a), metachromatic reaction with basic dyes (Solcia and Sampietro, 1965a, b) and electron microscopy (Caramia, Munger, and Lacy, 1965; Munger, Caramia, and Lacy, 1965) confirm this. From the above results it appears that, on properly fixed human islet tissue, both argyrophilia with Davenport silver impregnation and toluidine blue metachromasia are characteristic staining reactions for a cell type different from both $\alpha$ and $\beta$ cells. Thus, the possibility of a third noninsulin nor glucagon-producing islet tumour should be considered.

Our morphological investigation clearly indicates that tumour and hyperplastic cells from ZollingerEllison cases are not related either to $\alpha$ or to $\beta$ cells but display the cytological and cytochemical aspects of the argyrophil-metachromatic islet cells, as suggested before (Solcia and Bertoli, 1964; Cavallero and Solcia, 1965; Solcia, 1966). Accordingly, Franksson, Hellström, Hultquist, and Perman (1960), Goulon, Mercier, Reilly, and Laporte (1960), Martin and Potet (1962), Mieher, Hartsock, Geokas Ballard, and Frame (1962), Martini, Strohmeyer, Haug, and Gusek (1964), and Wegmann, Zollinger, 
and Markoff (1964) have noticed various degrees of argyrophilia in tumour cells; for example, positive silver impregnations were obtained by Potet, Martin, Thiery, Bader, Bonfils and Lambling (1965) who employed Hellerström's and Hellman's modification of Davenport's method, just as we did. No morphological relationships appear to exist between the argyrophil cells of these tumours and the argentaffin cells of intestinal carcinoids.

Since Gregory et al. (1960) and others have found that tumour extracts from cases of the ZollingerEllison syndrome show a gastrin-like activity, the question arises as to whether argyrophil-metachromatic cells in normal pancreatic islets also are concerned with the production and release of a gastrin-like substance. In this connexion, it should be recalled that argyrophil-metachromatic cells morphologically similar to the ones of pancreatic islets have been observed in the antro-pyloric mucosa of the stomach (Solcia and Sampietro, 1965b, c) where gastrin is normally present.

On histochemical grounds it may be suggested that the secretory granules in normal and tumoural argyrophil-metachromatic cells store an acid protein with several side-chain carboxyl groups closely arranged so as to give basophilia of metachromatic type. These histochemical data appear to be consistent with the chemical structure of purified gastrin as determined by Gregory, Hardy, Jones, Kenner, and Sheppard (1964) and by Bentley, Kenner, and Sheppard (1966).

\section{SUMMARY}

Cytological and cytochemical studies of six tumours and hyperplasias of the pancreatic islets associated with the Zollinger-Ellison syndrome have been performed by employing the most suitable methods for islet morphology. The results obtained suggest that the tumour and hyperplastic growths are not related either to insulin-producing $\beta$ cells or to glucagon-producing $\alpha$ cells, but originate from the argyrophil-metachromatic or $\delta$ cells. It was found that both normal and tumour argyrophil-metachromatic cells store in their cytoplasm an acid protein. On histochemical grounds a possible relationship between this protein and the hormone gastrin is discussed.

This work was supported by a grant from the Consiglio Nazionale delle Richerche, Roma (N. 115/1139/991).

We are greatly indebted to Professor R. M. Zollinger, Department of Surgery, the Ohio State University College of Medicine, Columbus, U.S.A., to Professor P. Stefanini, Istituto di Patologia Chirurgica, Università di Roma, Italy, to Professor C. Krauspe, Pathologisches Institut des Universitätskrankenhauses, Hamburg, Germany, to Professor A. Tardini, Istituto di Anatomia Patologica, Università di Parma, Italy, to Professor S. Donati, Clinica Chirurgica, Università di Pavia, Italy, and to Professor A. Trivellini, Clinica Chirurgica, Università di Milano, Italy, for supplying surgical and necropsy material from Zollinger-Ellison cases and insulinomas.

\section{REFERENCES}

Barrnett, R. J., and Seligman, A. M. (1958). Histochemical demonstration of protein-bound alpha-acylamido carboxyl groups. J. biophys. biochem. Cytol., 4, 169-176.

Bentley, P. H., Kenner, G. W., and Sheppard, R. C. (1966). Structures of human gastrins I and II. Nature (Lond.), 209, 583-585.

Bloom, W. (1931). A new type of granular cell in the islets of Langerhans of man. Anat. Rec., 49, 363-371.

Brown, C. H., and Crile, G., Jr. (1964). Pancreatic adenoma with intractdble diarrhea, hypokalemia, and hypercalcemia. J. Amer med. Ass., 190, 30-34.

Caramia, A., Munger, B. L., and Lacy, P. E. (1965). The ultrastructural basis for the identification of cell types in the pancreatic islets. I. Guinea pig. Z. Zellforsch., 67, 533-546.

Cavallero, C., and Solcia, E. (1963). Considerazioni sulla citologia insulo-pancreatica; esistenza e possibjle funzione di un terzo tipo cellulare. Riv. Anat. pat., 24, 1000-1018.

- (1964a) Cytologic and cytochemical studies on the pancreatic islets. In The Structure and Metabolism of the Pancreatic Islets, edited by S. E. Brolin, B. Hellman, and H. Knutson, pp. 83-97, Pergamon Press, Oxford.

,$--(1964 b)$ : Morfologia funzionale delle isole pancreatiche. Acta diabet. lat., 1, 5-31.

_- _ (1965). Cytological and cytochemical aspects of islet pathology in the Zollinger-Ellison syndrome. Rev. int. Hépat., 15, 517-526.

Fisher, E. R., and Lillie, R. D. (1954). The effect of methylation on basophilia. J. Histochem. Cytochem., 2, 81-87.

Franksson, C., Hellström, J., Hultquist, G., and Perman, G. (1960). Primary chief-cell hyperplasia of the parathyroids, and islet cell hyperplasia and adenomata of the pancreas associated with gastro-duodeno-jejunal ulcer. Acta chir. scand., 118, 270-277.

Goulon, M., Mercier, J. N., Reilly J., and Laporte, A. (1960). Carcinome langerhansien responsable d'hypersécretion gastrique acide, de diarrhée chronique, d'hypokaliémie sévère avec paralysies et d'hypoglicémie. Sem. Hôp. Paris, 36, 812-824.

Gregory, H., Hardy, P. M., Jones, D. S., Kenner, G. W., and Sheppard, R. C. (1964). Structure of gastrin. Nature (Lond.), 204, 931-933.

Gregory, R. A., and Tracy, H. J. (1964). A note on the nature of the gastrin-like stimulant present in Zollinger-Ellison tumours. Gut, 5, 115-117.

- - - French, J. M., and Sircus, W. (1960). Extraction of a gastrin-like substance from a pancreatic tumour in a case of Zollinger-Ellison syndrome. Lancet, 1, 1045-1048.

Greider, M. H., and Elliott, D. W. (1964). Electron microscopy of human pancreatic tumors of islet cell origin. Amer. J. Path. 44, 663-678.

Grossman, M. I., Tracy, H. J., and Gregory, R. A. (1961). ZollingerEllison syndrome in a Bantu woman, with isolation of a gastrinlike substance from the primary and secondary tumors. II Extraction of gastrin-like activity from tumors. Gastroentero$\log y, 41,87-91$.

Hallenbeck, G. A., Code, C. F., and Kennedy, J. C. (1961). 'Gastrin' of pancreatic origin. Ibid., 40, 679 .

Hellerström, C., and Hellman, B. (1960). Some aspects of silver impregnation of the islets of Langerhans in the rat. Acta endocr. (Kbh.) 35, 518-532.

Hellman, B., Rothman, U., and Hellerström, C. (1962). Identification of a specific type of a cell located in the central part of the pancreatic islets of the horse. Gen. comp. Endocr., 2, 558-564.

Karnovsky, M. J., and Fasman, G. D. (1960). A histochemical method for distinguishing between side-chain and terminal carboxyl groups of proteins. J. Histochem. Cytochem., 8, 326-327.

Lillie, R. D. (1958). Methylation and alkali demethylation. Ibid., 6 , 398-399. 
Lison, L. (1960). Histochimie et Cytochimie Animales, 3rd ed. GauthierVillars, Paris.

Manocchio, I. (1960). Metachromatische Färbung der A-Zellen in Pankreasinseln von Canis familiaris. Zbl. allg. Path. path. Anat., 101, 1-4.

Marks, I. N., Selzer, G., Louw, J. H., and Bank, S. (1961). ZollingerEllison syndrome in a Bantu woman, with isolation of a gastrinlike substance from the primary and secondary tumors. I. Case report. Gastroenterology, 41, 77-86.

Martin, E., and Potet, F. (1962). Anatomie pathologique du syndrome de Zollinger-Ellison. Arch. Mal. Appar. dig., 51, 281-300.

Martini, G. A., Strohmeyer, G., Haug, P., and Gusek, W. (1964). Inselzelladenom des Pankreas mit urtikariellem Exanthem, Durch-fällen sowie Kalium- und Eiweissverlust über den Darm. Dtsch. med. Wschr., 89, 313-322.

McManus, J. F. A., and Mowry, R. W. (1960). Staining Methods. Hoeber, New York.

Mieher, W. C., Hartsock, R. J., Geokas, M. C., Ballard, H. S., and Frame, B. (1962). Peptic ulcer as a manifestation of familial polyendocrine disease. J. Amer. med. Ass., 179, 854-858.

Munger, B. L., Caramia, F., and Lacy, P. E. (1965). The ultrastructural basis for the identification of cell types in the pancreatic islets. II. Rabbit, dog and opossum. Z. Zellforsch., 67, 776-798.

Pearse, A. G. E. (1960). Histochemistry. Theoretical and Applied, 2nd ed. Churchill, London.

Petersson, B., Hellerström, C., and Hellman, B. (1962). Some characteristics of the two types of A-cells in the islets of Langerhans of guinea-pigs. $Z$. Zellforsch., 57, 559-566.

Potet, F., Martin, E., Thiery, J. P., Bader, J. P., Bonfils, S., and Lambling, A. (1966). Etude histologique et cytologique du pancréas endocrine, tumoral et non tumoral dans le syndrome de Zollinger-Ellison. Rev. int. Hépat., 16, 737-761.

Priest, W. M., and Alexander, M. K. (1957). Islet-cell tumour of the pancreas with peptic ulceration, diarrhoea and hypokalaemia. Lancet, 2, 1145-1147.

Rawson, A. B., England, M. T., Gillam, G. G., French, J. M., and Stammers, F. A. R. (1960). Zollinger-Ellison syndrome with diarrhoea and malabsorption. Ibid., 2, 131-134.

Schiebler, T. H., and Schiessler, S. (1959). Über den Nachweis von
Insulin mit den metachromatischen reagirenden Pseudoisocyaninen. Histochemie, 1, 445-465.

Scott, H. R. (1952). Rapid staining of beta cell granules in pancreatic islets. Stain Technol., 27, 267-268.

Selli, M., Baglioni, A., and Castrini, G. (1963). La sindrome di Zollinger-Ellison. (Rassegna sintetica-contributo clinico). Chir. gen. (Perugia), 12, 117-155.

Sircus, W. (1964). Evidence for a gastric secretagogue in the circulation and gastric juice of patients with the Zollinger-Ellison syndrome. Lancet, 2, 671-672.

Solcia, E. (1966). Le basi morfologiche e patogenetiche della sindrome di Zollinger-Ellison. Arch. ital. Chir., 92, 3-40.

$\longrightarrow$, and Bertoli, G. (1964). Studio citologico di un tumore insularé con sindrome di Zollinger-Ellison. Boll. Soc. ital. Pat., 8, 229-232.

- and Sampietro, R. (1965a). On the nature of the metachromatic cells of pancreatic islets. $Z$. Zellforsch., 65, 131-138.

- - (1965b). Cytologic observations on the pancreatic islets with reference to some endocrine-like cells of the gastrointestinal mucosa. Ibid., 68, 689-698.

,$- \quad(1965 \mathrm{c})$. Osservazioni sulla basofilia delle cellule argentofile e di quelle enterocromaffini. Riv. Istochim. norm. pat. 9, 265-278.

Summerskill, W. H. J. (1959). Malabsorption and jejunal ulceration due to gastric hypersecretion with pancreatic islet-cell hyperplasia. Lancet, 1, 120-123.

Thomas, T. B. (1937). Cellular components of the mammalian islets of Langerhans. Amer. J. Anat., 62, 31-57.

Wegmann, T., Zollinger, H. U., and Markoff, N. G. (1964). ZollingerEllison-Syndrom mit terminaler letaler Hypoglykämie. Dtsch. med. Wschr. 89, 2223-2228.

Zollinger, R. M. and Craig, T. V. (1960). Ulcerogenic tumors of the pancreas. Amer. J. Surg., 99, 424-432.

—, Elliott, D. W., Endahl, G. L., Grant, G. N., Goswitz, J. T., and Taft, D. A. (1962). Origin of the ulcerogenic hormone in endocrine induced ulcer. Ann. Surg., 156, 570-578.

- , and Ellison, E. H. (1955). Primary peptic ulceration of the jejunum associated with islet cell tumors of the pancreas. Ibid., $142,709-728$. 